\title{
The Honourable Merchant-Why We Need to Educate Not Only Our Minds, But Also Our Hearts
}

\author{
Gabriele Sigg \\ Freelancer, Berlin, Germany.
}

\begin{abstract}
How to cite this paper: Gabriele Sigg (2021). The Honourable Merchant-Why We Need to Educate Not Only Our Minds, But Also Our Hearts. The Educational Review, USA, 5(6), 172-181.

DOI: $10.26855 /$ er.2021.06.003
\end{abstract}

Received: May 10, 2021

Accepted: June 5, 2021

Published: June 30, 2021

Corresponding author: Gabriele Sigg, Freelancer, Berlin, Germany.

Email: kontakt@gabrielesigg.de

\begin{abstract}
Until the present time, it has been a widespread belief that solving economic problems requires stronger enforcement of rules and creating more laws. Instead of the former bartering system of commerce, today we have fixed prices and instead of a "handshake sealing the deal" between tradesmen, we use written contracts. Formal rules in different formats are supposed to minimize human greed and other failures of human character that can show up in commerce and trade. The "formalization" of the world however has not really solved these human problems, and it has overlooked an important aspect: The Person (Arendt) and their subconscious cultural patterns and character flaws. While traditional economies not only taught special knowledge or a craft, but also felt obliged to shape the learner's character, modern society and businesses fail to combine these two important features. In the theoretical traditions of Plato, Aristotle, Adam Smith, Hannah Arendt, Emile Durkheim and Georg Simmel, this article aims to show the interrelationship between the acting individual and formal rules of society within the category of "The Person" (Arendt). Therefore, the author presents the thesis that a person's character is more important in its contribution to society than following formal rules. In order to support the thesis, the author provides examples from commerce and trade at the Grand Bazaar in Istanbul, Turkey, which she examined in her Ph.D.-Thesis. Therefore, the "Education of the Person" in form of "Emotional Education" and "Education of the Heart" should be reintegrated in our education systems.
\end{abstract}

\section{Keywords}

Aristotle, Adam Smith, Hannah Arendt, Grand Bazaar Istanbul, Traditional Economy, Character building, Honour, honour killings, virtue, Trading-Honour (Handelsehre), Emotional Education, Education of the Heart

\section{Introduction}

In traditional society, the term honour applied to private as well as public life. Especially in private life, a woman's honour was defined and supervised by the whole community and her first duty was to stay a virgin prior to marriage. In other words, this notion of her honour reduced her to a sexual item of property that was owned by her husband, as the head of the family. Western countries now know of this mainly from other countries, especially from the Middle Eastern or Mediterranean "Honour and Shame-Societies" (Peristiany, 1965; Pitt-Rivers, 1971 [1954]; Petersen, 1985; 
Hüwelmeier, 2004). But it was not so long ago, that this patriarchal understanding of honour was the norm for women in Western countries as well. As an example, in Germany, as recently as 1997, and after 25 years of fighting for protection for married women, it was finally recognized that marital rape was a violation of a woman's rights, and laws criminalizing this act were passed (Gerste, 1997). The most brutal form of this misuse of the word "honour" led to what today are called "honour killings" which often is the only exposure and understanding to the word "honour" most people and scientists (Schiffauer, 1983) today have.

This whole, almost manic focus on the gendered and misused honour construct has led ethnologists and sociologists to overlook another traditionally important part of honour: Honour in public life related to the idea of an "honourable merchant". While the honour between a man and woman has had to be repeatedly renegotiated in Modernity, traditional understandings of honour in economics can give us useful ideas for the importance of not just educating the Mind, but also the Heart of one's Person. In my Ph.D.-thesis, I investigated the concept of an honourable merchant in case studies conducted at the Grand Bazaar in Istanbul (Sigg, 2017). ${ }^{1}$

The Grand Bazaar is one of the oldest trading centers in the World. Today, Western concepts of commerce with fixed prices and contracts have been adopted throughout Turkey's economy with an exception in the Grand Bazaar, which maintains its unique traditional position. Within the Turkish economy as a whole, the Bazaar remains the hidden heart (Küçükerman/Mortan, 2009, p. 188) and like the Basaris (Grand Bazaar merchants) call it lovingly: "the Mother of trade” (Turk.: “ticaretina nnesi”) (Sigg, 2017, p. 116).

Throughout centuries different religions (Christians, Jewish, Sunnit and Alawite Muslims) and ethnicities (Turks, Kurds, Armenians, Syrians - and lately also Europeans) worked and lived together in peace and harmony (Özbey, 2010, p. 244; Sigg, 2017, pp. 235-261). This mandated a common ground of values beyond cultural or religious belief systems and can be found in the sense of honour that lies as a possibility within all human beings (Aristotle 1103a-1103b).

\section{The Honourable Merchant as exemplified at The Grand Bazaar in Istanbul}

The traditional apprenticeship-system was based on a personal relationship between apprentice and master. It was a system of: apprentice - journeyman - Master (Turk.: çırak - kalfa - usta). The values learned were developed first in the home and family, before being refined and expanded on during the apprenticeship by the master. The apprentice was therefore not any anonymous human being, but, if not studying under his own father, became a part of the whole family of his master (Simmel, 1992, p. 503).

"All medieval guilds were based on the hierarchy of the family, but these were not necessarily blood ties. The master craftsman legally stood in loco parentis to the journeymen and apprentices below him, even if they were not his kin. A father entrusted his sons to the master craftsman as a surrogate parent most notably by transferring the right to punish misbehaviour with physical violence.” (Sennett, 2009, p. 62f)

At the Grand Bazaar in Istanbul, all the traditional Basaris (merchants at the Bazaar) have learned their craft in apprenticeship. Primarily, they spent time at the Bazaar in the store of their father from a very young age, starting as early as six or seven (Sigg, 2017). In the traditional apprenticeship-system, one not only learned a craft or knowledge, but also was educated as to personal character and virtues of the heart. "And in the goldsmith's case, the good skills that established the master goldsmith's authority were inseparable from his ethics. This ethical imperative appeared in the very technological activity, the assay, that gave goldsmithing its economic value. Corrupt, shaved, and false coins assailed the medieval economy. The goldsmith's role was to smelt gold from raw ore. The honour of the guild was meant to reinforce honesty; goldsmiths discovered to be dishonest were violently punished by other guild members." (Sennett, 2009, p. 61)

In the case of Turkey, the apprenticeship system called "Ahilik", which we first found mentioned in the 13th century in central Anatolia, was the traditional apprenticeship system. The founder of "Ahilik" was Ahi Evren. His birth name was Nasırüddin Mahmud B. Ahmed (1171-1262). The name "Evren”, meaning "cosmic" or "universal”, was given by others because the fundamentals of apprenticeship education were considered both general and universal. (Çağatay, 1990, p. 10; Küçükerman/Mortan, 2009, p. 67; Solak, 2010, p. 9f). "Ahilik is a cooperative, where art, craftwork and

\footnotetext{
${ }^{1}$ To make it clear: Like everywhere else in the world and as already been presented in different sociological studies (Korff 1966, Veblen 1899, Riesman 1950), there has been a shift from a sense of inner honour to the concern for reputation (outer honour). The aim of my investigation was not to ask if there is still more honour at the Bazaar than in other parts of the world, far more than that my thesis was a work to describe, and demonstrate with case studies, what the function and use of an honourable attitude in business is by looking closely at the older tradesmen practices at the Grand Bazaar in Istanbul. As a whole I conducted field work at the Grand Bazaar seven different times between the years 2008-2015. Twice I stayed for a period of 8-9 months. I participated in trade in different shops (e.g. carpentry, jewellery, pottery, handbags) and spoke (qualitative interviews) with both older and younger generations of merchants (for more Information Sigg 2017, 16ff).
} 
trade, morals and truthfulness, were taught as part of the process of becoming a mature person. A person who refers to Ahi, and therefore is remembering the Person Ahi, is a true craftsman, a tradesman, or the owner of any other kind of craft. This reference and remembrance is the mark of a mature, virtuous, merciful, benevolent and, in all of his work and behaviour, an honest and trustworthy person.” (Çağatay, 1990, p. 6). The Ahilik-system is designed as a process made up of stages that build one upon the other. The first stage is called the yamak (helper), followed by the çırak (apprentice), kalfa (journeyman), and finally the usta (master). It takes about 1,000 days, or three years, to move through one stage to the next (Çağatay, 1990, p. 8; Şatıroğlu/Okan, 2010, p. 24ff).

Ahilik comes from Arabic and means brotherhood. The Prophet Mohammed (570-630) was a tradesman and was born into a tradesman's family. As a young child, his uncle took him along during his business travels and, a little bit later, he started trading himself. He developed a well-known reputation for being a clever as well as an honest tradesman, who would never betray his clients' trust and was never betrayed by them (Köknel/Ortayl1, 2007, p. 24). While Mohammed was alive the institution of "Hilf'ulFudul" (The Oat of virtue) arose and was afterwards followed by "Füttüvet". Ahilik was inspired by Füttüvet, but freed itself from any religious connection in order to be able to face the upcoming challenges of the new Turkish Society (Köknel/Ortayll, 2007, p. 52f). Ahilik was replaced by the guild-structure in the $18^{\text {th }}$ century. "The master-apprentice relationship constituted the basis of the guilds. Apprentices who started to work at very young ages would work under supervision and in accordance with the strict discipline of their masters. They learned the fine skills of their craft, and then passed that on to the next generation through this relationship. Promotion of an apprentice to the status of kalfa was subject to the approval of the guild's executive board. Such promotions would be marked with a "Wearing of the Apron" ceremony. Being the guilds most important function, regulation of the guilds was maintained through such face-to-face relationships.” (Pamuk, 2001, p. 47)

In the traditional Turkish economy one thought not just about their own business. "Siftah" was the name for the first business of the day, which was supposed to bring a good business day. If one tradesman did his "siftah", he would send the next client to his neighbour so he could also be happy, as happiness cannot be in oneself, if another is suffering (Sigg 2017, p. 150). This way of conducting business is reminiscent of Adam Smith's “Theory of Moral Sentiments”, where he emphasized the human capacity to not think only of oneself, but also of others. "No matter how egoistic one can consider mankind, there are evidently certain principles in his nature that make him decide to share in the fate of others,and to make him want bliss for those others, although he receives no other benefit than the pleasure of witnessing it" (Smith 2010, p. 5). Unfortunately, this first book by Adam Smith was greatly overlooked and therefore the "Wealth of Nations" was not correctly understood, as it states that humans not only look out for their own interests, but also have the capability and need to see other people being happy.

Justice in trade was a central principle of the Ottoman Empire. With the ending of the Empire and the beginning of the Republic, along with the incorporation of Industrialization and Capitalism in the $19^{\text {th }}$ century, the traditional economic structure began to decline and guilds gradually disappeared entirely (Küçükerman/Mortan, 2009, p. 124ff). With the disappearance of the traditional economic apprenticeship system the education of ethical virtues disappeared as well. Sociological studies have shown the change in personal character from an "inner honour" (virtue, integrity, conscience) to an "outer honour" (prestige, reputation, fame) as economic and social systems have transitioned from traditional to modern societies (Korff, 1966; Veblen, 1899; Riesman, 1950), which lead to more selfishness in business as well. The Turkish term for inner honour in trading is "dürüst” and the term for outer honour or prestige is "şeref" (Sigg, 2017, p. 87).

The idea of an apprenticeship-system being responsible to build personal ethical virtues has occurred and vanished in history numerous times, which led Durkheim (1991, p. 34; 1992, p. 48ff) to see the "Berufsgruppen" (professional groups) as the most important place for developing ethical virtues in modern society, because the traditional concept of the family has declined (see also Müller/Schmid, 1992, S. 490). Modernity separated the building of virtues from one's physical or intellectual work. "Learning economics, it seems, may make people more selfish." (Hausman/McPherson, 1993, p. 674)

With globalization and modernization, the old Bazaar was challenged by new circumstances. In the 1960s, the Grand Bazaar was the main place to shop for local Turks: from household goods through the wedding dress, everything was bought at the Bazaar. In the 1980s, Shopping Centers became the new vogue and forced the Bazaar to change. Mass tourism, cheap products from countries like China, Afghanistan and Pakistan, as well as the introduction of the Internet in the 1990s, challenged the Bazaar further to re-invent itself (Küçükerman/Mortan, 2009, p. 184ff; Şatıroğlu/Okan, 2010, p. 109; Stewig, 2009). Today, the shopping malls are not the big threat they once were, as they can't compete with the unique offerings and atmosphere of the Grand Bazaar. However, the cheap products from China, coupled with the increase in tourism numbers but decrease in per person spending, is a burden for the Grand Bazaar that has contributed to its traditional structure becoming fractured. Also, traditional trading practices integrated into the traditional 
personal apprenticeship program, have been challenged by the more modern understanding of law and order. This can be observed in the comparison of the "principle of need" (traditional economy) vs. the "principle of equality" (modern economy).

\section{Principle of need vs. Principle of equality_Eastern vs. Western trading patterns}

The dynamic of tradition and modernity is reflected also in the dynamic of Western and Eastern countries. In the confrontation of fixed prices vs. bargaining as well as the handshake vs. the contract, we can see the different principles of justice. One is the "principle of equality", which is mainly promoted by John Rawls $(1971,1993)$, and the other, the "principle of need”, mainly promoted by Aristotle (Röhl, 1987/2013, p. 165ff; for a detailed explanation see Sigg, 2017, pp. 165-206). Due to Sombart (1913, p. 17), Aristotle was the one who understood the nature of the traditional economy the deepest.

The "principle of need" (Aristotle) perceives justice as relative, depending on time, person and situation. In his "Nicomachean Ethics", Aristotle showed the necessity of educating the mind as well as the heart. The building of the character by virtues was seen as essential for the citizen in the Polis as well as for trading. Aristotle distinguished between the ethical and dianoetic virtues. The ethical virtues relate to the educating of the heart, which is the source of ethics, while the dianoetic virtues describe the education of the mind or the intellectual part of human existence (Aristotle, 1102a-1103b). Justice as a virtue, compared to other virtues, is seen as one of the most important, and also as being important in all aspects of life (Aristotle, 1130a; see also Plato, The State, 332-334).

Contrary to this, the "principle of equality" assumes an absolute understanding of justice, where everyone for instance is required to pay the same price for the same product, independent of one's income or status. John Rawls is a representative of the "principle of equality" (Röhl 1987/2013, p. 165ff) and the contract theory (with Hobbes, Locke and Hume). The theory of the contract comes from an attempt to rationalize and legitimizing a political perspective reflecting the protection of the rights of free and equal individuals (Kersting, 2002, p. 163). It is mainly based on the use of intellectual reasoning, but lacks an understanding with intuitive reasoning.

To make it clear: I am not refusing these theories or the "principle of equality" in general. I want to demonstrate that it is related to a biased, and therefore limited cultural understanding, and also is only a part of what justice is, and that it is not sufficient on its own. Now is the time for these two different cultural perspectives to come together and find common ground.

Aristotle described both principles, but in modern societies, the "principle of equality" is primarily practiced, and there is a lack of acceptance and understanding of the "principle of need". These principles lie within all cultural patterns, which in general we are not aware of, yet act out unconsciously. Without understanding the different cultural patterns of thinking and (emotional) reacting, and reflecting on our own patterns, we cannot address the possibility of a common "World Ethos" (Küng, 1991). This "Golden Rule" described in the "World Ethos" and in different Religions, and already having existed in Archaic Societies (Mauss, 1966) and in Philosophy (Aristotle), is very much connected to our heart-consciousness and ethical understanding, which is why the Western World must also understand the "principle of need”. In traditional societies, considering one's own personal benefit (i.e. Profit or advantage) was not neglected but had to be subordinate to this "sense of honour", which could also be described as a "sense of justice" or a "matter of honour". This stands in contrast to an abstract or rational understanding of equality (see Bourdieu, 2000, p. 46). The sense of justice or honour, as well as the matter of honour, belong to the "principle of need" while abstract and rational understandings of justice belong to the "principle of equality". Therefore, trading in Modern societies is based on equality and abstraction, while trading in traditional societies is based on one's need. Western logic makes a huge mistake, if it continues to perceive itself as the only just one, as it lacks a real understanding of other forms of justice.

To make these abstract sounding principles more understandable, the Grand Bazaar in Istanbul provides a perfect setting in which to study the two principles, which are both in daily practice. Currently, trade at the Grand Bazaar is conducted primarily by bargaining (principle of need), however the idea of Fixed Prices (principle of equality) is well-known and often a topic of discussion among merchants. This is due to several influences including: exposure to doing business with Western tourists, the fact that several shop owners are now working with price tags, and that most of the rest of Turkey's economy has become very Westernized.

In addition to the different practices of Bargaining and Fixed Prices, the Honourable Merchant in a traditional economy did not need a contract (principle of equality) as his handshake (principle of need) was a "Word of Honour". To stick to one's word was something that a person owed to himself and did not need to be enforced by an external authority like the state. Therefore, the comparison of "Bargaining vs. Fixed Prices" as well as "a Handshake" vs. a Contract" will help us become grounded in these two abstract sounding principles. 


\subsection{Bargaining vs. Fixed Prices}

For the Western mind, it is clear that prices must be the same for everyone, independent of their income or social status. While the argument for equal pricing independent of social or economic status is fair and ethical, it is not necessarily just, if people have to pay the same price for a product when they have less means to do so (principle of need). At the Grand Bazaar it is common practice that foreigners pay more than Turkish citizens, and even among foreigners the prices vary according to what country a person is coming from. Someone from India does not pay as much as a person from the US or Germany. Westerners tend to get angry about this and claim it is unjust. However, it would be incorrect to conclude that a bargained price can be just anything at all. In order to effectively perceive fixed prices or trading as just, the category of "The Person" and personal character, must be taken into account. In our measured (academic) world this poses a huge problem, because "the Person" and "Honour" are concepts that can't be measured. Qualitative and hermeneutic approaches and methods are required in order to grasp an understanding of these categories.

"If you betray someone else, you will lose yourself” ("Kandirdiğl zaman kendisi kaybeder."), say the old tradesmen (Sigg, 2017, p. 86). Therefore, in traditional economies, while apprentices were learning a craft and being schooled on how to be honourable tradesmen and truthful about their products, they were also being taught about honourable behaviour and their responsibilities toward compensating their workers and suppliers well. Because of this, tradesmen had a much greater responsibility to consider when bargaining, than simply making personal profit. Understanding this provides a more complete context for working within the principles of fairness and justice when bargaining without fixed prices. Understandably having no fixed price does not mean no price limits at all. It means there is not one price, but instead there is a price range that the merchant knows he must bargain within in order to meet his responsibilities to all involved. Of course, the Basari keeps this price range to himself. If the price is fixed, one cannot fairly take into account what is needed in this situation for everyone. What is fair, is determined in this moment depending on the circumstances and on the mutual agreement of both parties. As everyone has agreed on it in an honest and honourable way, it is fair. Fixed prices limit the ability of people to decide what is fair or not in any given situation, by their own sense of honour. Certainly, if a sense of honour is not educated, it is a problem.

It is a very modern notion, that prices, or the weighing of products, needs to be exact. Specifically this is modern in that the calculation of a price cannot be a rough estimate but needs to be an exact amount. In a traditional economy one was thinking more of qualitative approaches and not so much in quantitative measuring. It was the qualitative relationship towards the economic goods (principle of need; G.S.) that was relevant for trading. This is related to the developing intellectual thinking, which separated human beings from their intuitive intelligence (Sombart, 1913, p. 18f).

The Western mind is based on quantitative rationality and mechanical thinking and, believing that this is the only just way to do business, wants to measure the whole world. Eastern and Traditional thinking is more integrated into a holistic qualitative world view (Bourdieu, 1976; Bourdieu, 2000; Mauss, 1966). Almost everything that the Western mind would consider as just in commerce, is based on a cultural bias. I would not argue that it is totally wrong. I would argue that it is just "half of the cake". One might observe that one half of the world focused on specializing in one principle, and the other half of the world in the other principle. In order to find any cultural understanding, or a common "World Ethos" (Küng), the Western world cannot continue to impose its bias on other cultures or stay ignorant of the justice present in other ways of conducting commerce, as is demonstrated at the Grand Bazaar. This same bias is seen in a comparison of the handshake vs. the contract.

\subsection{Handshake vs. Contract}

In the carpet business, we can learn a lot about the different principles of equality and need, as demonstrated in the practices of the handshake and the contract. One of the most famous makes of carpet in Turkey is the "Hereke-silk-rug". Hereke is a town in Turkey, which is famous for these special, silk rugs, as different regions are famous for different crafts. Original silk rugs from Hereke are handmade with natural colours that last for hundreds of years. With the mass production opportunities now available in China, some carpet merchants started selling cheap imitations purchased from China and passing them off as Hereke silk rugs. These imitations are of much inferior quality, made by machines and with chemical colours. However, at first glance, even the very experienced carpet merchants found it difficult to detect the difference by sight alone. Sometimes only when they touch them could they tell these rugs were fakes, by looking at the quality of the knotting. The customers discover the difference after taking them home and seeing how they showed signs of wear, and lost the quality of their beautiful colours, so very quickly. Selling carpets from China in and of itself is not the biggest problem. It is in deceiving the customer, and therefore not behaving as an honourable merchant, that poses the biggest offense. (Sigg, 2017, p. 75f, p.119f).

In spring 2014, while doing my fieldwork at the Grand Bazaar, a law suit was filed. A German woman bought carpets 
at the Grand Bazaar and found out later that those carpets were not from Hereke, as she had been told. These fake carpets were sold to her for $28.000 €$, but their worth was actually only $3.000 €$, as she found out later (Dinçer, 2014). In order to prevent these types of situations, the practice of using contracts to sell carpets is spreading. One would think that this would make the dealings safer for the consumer but in fact it is often the opposite, as a traditional carpet merchant confesses (Sigg, 2017, p. 168):

"I see people who work in such a (fraudulent) way prepare contracts where the quality of the product is "guaranteed" to be much higher than it actually is. If the customer comes back to confront the merchant the merchant shows the signed contract as proof of agreement to the sale. For example, I do not need such a thing (a contract) at all, and so far no customer has ever brought anything back. [...]"

This demonstrates how the right idea, like authoring a contract to minimize unbridled human greed, can be used for its opposite intent. This is not unique to the Bazaar but found throughout many aspects of daily life. Personally, when I sign a contract, the first thing I look at is the small print, as it can actually negate, in many ways, the whole content of the contract. Today, the exploitation meant to be prevented by contract laws is often hidden in the small print of contracts. Durkheim talked about the social-preconditions of a contract in the famous 7th chapter of his book: Division of Labour: "Not everything is contractually in the contract." (Durkheim, 1992 [1893], p. 267). The "principle of equality" (fixed prices, contracts) is based on abstract thinking. It anticipates what it guesses will be needed in the future. This is a great human capacity, but no one can foresee all the details of all future possibilities. Therefore, flexibility regarding possible unforeseen changes to circumstances needs to be allowed. What was agreed on in the contract can end up being unfairly adhered to if one of the contract parties' situation has changed e.g. an illness or unforeseen loss of money. Additionally, if both parties enter into a contract without concern for justice, but with the intent of taking unfair advantage of the other party for their own personal gain, then already the contract would be based on wrong intention in a traditional economic understanding.

\section{Economy, Culture and Emotions}

There is this cultural judging of "personal" - "impersonal", which is wired into the western brains and habitus as "unjust" - "just", or "subjective" - "objective" which is never scrutinized. In Western cultures, benefit could be derived from confrontation with other cultures' way of doing things, if in doing so they could rise above their own cultural biases.

Many visitors from Western countries expect the Basari to be truthful according to their own culture's definition of that word, and easily judge them for taking more money from a foreigner than from a Turkish customer for the same goods. I am not saying by this that there is not some unjust trading that occurs at the Bazaar on an individual basis, or that every Basari is an Honourable Merchant. I am presenting an aspect of cultural influence that results in moral judgements being made, about another culture's practices, based primarily on unconscious cultural biases, rather than on any truly objective understanding of morality. This occurs because of the different beliefs about the value or validity of the "principle of equality" vs. "principle of need". Under this influence, Westerners tend to overlook the lack of integrity within their own economic system. As examples, today we think it is normal to be bombarded by huge billboards, junk emails, snail mail flyers, Facebook, YouTube, television commercials, and other forms of advertisements, everywhere we go. We think this is normal but get offended by what the Western culture considers "verbal harassment" by the Basari, doing the same thing as the billboards, but in person, where one at least has the opportunity to interact in the moment, or tell the Basari directly to stop. With the Western forms of "digital harassment" there is no opportunity, in the moment or at any time, to engage directly with the sender or tell them to stop. One of the benefits of this personal engagement conducted at the Bazaar is that, for good or bad, one always has direct access to the person and is, therefore, empowered to directly and immediately effect the situation. This "digital harassment" is just an algorithm constructed by a third party who is never made accessible or even identified. These examples demonstrate that extracting "The Person", as is being done in the "principle of equality" and modern economy, does not solve the problem of human greed or address any other character flaws, but only allows them to show up in another form, which can be even worse.

Traditional economies did not consider advertising itself as bad manners, but only if done in the way Sombart described in the following paraphrased way: An advertisement in and of itself is not considered dishonourable in a traditional economy, but an ad that made one's own shop appear better than others', or referred to special advantages, was considered bad manners. The highest degree of bad manners in commerce was the announcement of cheaper prices than one's competitors (Sombart, 1913, p. 204).

In addition to the way a product is promoted, the content of an ad should, at the very least, be truthful, without deception of any kind. Western tourists easily judge the Basari when he lies, but tend to overlook, and never get angry about the lies in their own economic system. For example, a shampoo-advertisement may tell women what brilliant product 
will make their hair shinier, stronger, voluminous or whatever, sending the message that she is not good enough as she is. There is a yoghurt, that is supposed to have a special kind of bacteria which will make one more healthy and less fat. Or there is this running shoe, which will enhance one's performance level, without care to how many children had to suffer for its manufacture. Western advertising lies to potential customers every day about enhancing their lives in ways that are known to not be true-but it is easier to blame the Basari and other cultures, as our own cultures reinforce our individual instances of being judgmental, rather than seeing these confrontations as an opportunity to take a second look at our own culture's biases and failings.

We want to solve economic problems but lack the insight that recognizes each country's economy as part of a culture, which is incorporated into its people, their emotions and their mindset. One cannot just solve them by applying new rules or laws as their incorporated into human bodies and emotions. Today it is already widely known, that it is not the ratio making decisions, but the emotions decide much more time in advance on a subconscious level and give rational explanations later (see e.g. Damasio, 2005; Goleman, 1996).

Economic patterns are basically patterns of behaviour that developed within a culture. Religions exerted strong influences on these cultures over many centuries. We know this e.g. from Max Weber's work "The Protestant Ethic and the Spirit of Capitalism". Although today, especially in academic environments, we mainly see ourselves as non-religious, we are deeply shaped by religion through its historic effect on our culture on an emotional level. Although it might not be obvious to us in our average, daily-awareness, as we are not taught to observe ourselves or the effects of our subconscious moods and emotional reactions. So to, our moral-codes and sense of integrity are not always objective, but sometimes distorted or heavily biased. Our moral-codes especially are mainly subconsciously shaped and never reflected upon sufficiently, which would be needed to be done in our educational systems.

By looking at a culture that is different from our own, we can more easily see things that are lacking in our culture. This does not mean that nothing is lacking in the culture we are observing, as that culture also needs us to see what they are lacking. In general, it is the Western world that is judging a lot of other countries. While those judgements can sometimes be true, the Western world never allows themselves to see their own faults and weaknesses. This is why when Westerns demand that other cultures accept their principles, they first need to objectively look at those principles as through the eyes of that other culture. Cultural structures lie within ourselves, within "The Person", so that is the place where they can be changed, to hear one's inner voice (Plato/Hannah Arendt) and recognize one's sense of honour clearly.

\section{Why we need not only to educate our Minds, but also our Hearts}

"The Person" is not something subjective or personal. "The Person" is the place where objective structures and personal needs interact. The Education of our Heart and Emotion is placed in a Human Being and not outside of it. It is "The Person" who decides how to use formal rules, how to handle a law, or how to set a price (fixed or unfixed). He or she can change something for the better, towards being more just, or toward the worse. One can see this clearly in the case of "Eichmann in Jerusalem" (Arendt, 2013). The concept of "The Person", in this philosophical sense, transforms the division of subjectivity and objectivity. This does not mean that both do not exist, but they exist according to how one acts within, and applies their understanding of the laws. This is what can possibly do harm if one acts in opposition to the original, just, intention of the law.

"To put it another way, the greatest evil committed is evil done by nobodies, that is, by human beings who refuse to be Persons.” (Arendt, 2016, p. 101)

In reference to Hannah Arendts' concept of "The Person", we have to consider, that she invented it mainly in her explanation of the "Banality of Evil" in her book "Eichmann in Jerusalem". Eichmann, a former SS-Man, was responsible for the deportation of the Jews in Germany's National Socialism. Certainly, at first glance, this is not a crime of the same degree as that of a tradesman or merchant, as the banker on Wall Street for instance. But a second look reveals that possibly it is, as it was his financial speculating on rice, where thousands of people ended up starving. A banker, or other type of speculator, would not consider themselves a murderer of thousands or millions of people, just as Eichmann did not ${ }^{2}$. Eichmann saw himself as a bureaucrat who did nothing wrong because he simply followed orders and obeyed the laws. This seemingly justified action of obeying orders and following laws, is his true crime. This then mandates questioning, how much based in truth and justice, laws and official orders can be? The biggest crime Arendt

\footnotetext{
${ }^{2}$ I won't discuss the different critique Arendt received on her thesis as the Protocolls of Sassen or others who claimed Eichmann was pretending something Arendt took in. None of the critique can really refute the brilliant interrelations Arendt identified and authored in the concept of "The Person". The most challenging part in the analysis is the personal betrayal one has to face when reading her book, as their can be an "Eichmann" in everyone of us.
} 
(2013; 2016) saw with Eichmann is that he forgot the most specific human thing: To THINK. "In the realm of words, and all thinking as a process is a process of speech, we will never find an iron rule that will help us to determine with certainty what is right and what is wrong." (Arendt, 2016, p. 65)

While the experience of thinking today is believed to be primarily an action of neuronal activity in the brain, thinking from the perspective of Philosophy, back to Plato and Aristotle, goes beyond this limited understanding of the rational mind. Furthermore, it is considered a co-creative dialogue which goes beyond the subjective and rational understanding, but is led by everyone's inner voice (Arendt, 2016, p. 26) —and actually especially the Heart. — "Morality is about the individual in his uniqueness. The criterion of right and wrong, the answer to the question, 'What shall I do?', ultimately depends neither on habits and customs that I share with others living around me, nor on a command of divine or human origin, but on what I decide for myself. In other words, I can not do certain things because afterwards I would not be able to live with myself. This self-coexistence is more than awareness, more than the self-awareness that accompanies me in everything I do and in whatever state I am in. To be with myself and judge for oneself is articulated and updated in the process of thinking, and every process of thinking is an activity in which I speak with myself about what I am concerned with.” (Arendt, 2016, 81)

The Merchant is a Person, so he has the capacity to think and decide what is right (honourable) or wrong. It is his or her own decision. He or she does not need a contract or fixed prices to act rightly, he knows it, if his ethical virtues are developed enough - this is the way trade was done in archaic societies (see Mauss, 1966). A law or any formal rule (e.g. fixed prices, contracts) always has a gap, and so a need to start re-implenting character building in the different stages of the education system. This is not only a task for economy, but also one of society as a whole, as economy is supposed to be part of a society and not be "colonized" (Habermas, 1981) by economy.

A sense of honour exists as a possibility in every human being, but as with any talent, it needs to be developed or it will not flourish (Aristotle, NE 1103a-1103b). While in the traditional guilds, character building was integrated into the whole apprenticeship program, modernity lacks the combining of these two important things. Passing more laws will never solve the problem of human greed. When one does not want to do the right thing, he will always find a way to use a law, a contract, or any other formal rule, wrongfully, for their own personal gain.

Therefore, I believe that the education of one's character (Education of the Heart and Emotions), is a necessity nowadays. This cannot be done in any short-term period, but is a real long-term solution. We must therefore again see economies as part of culture.

Modern apprenticeship-systems therefore (from Kindergarden through middle school, universities and labour training institutions) should again implement the education of "The Person" (Heart and Emotions), who is able to be in a dialogue within themselves (see Sigg/Zimmermann, 2018). This moral training is unique and will not impinge on one's freedom and individuality. At the same time, the well-recognized inner voice will stop human greed and develop a truthful person instead of a well-optimized performer. Then at some point in the future, there will no longer be a need for so many laws as Aristotle knew, as Humanity will act out of kindness and justice not only, because anybody forced them to do, but because of an inner understanding, they learned from early childhood on. The time is now to plant the seeds.

\section{References}

Arendt, Hannah. (2013) [1963]. Eichmann in Jerusalem. Ein Bericht von der Banalität des Bösen. München: Piper. [Eichmann in Jerusalem. A report on the Banality of Evil]

Arendt, Hannah. (2016). Über das Böse. Eine Vorlesung zu Fragen der Ethik. München: Piper. [Responsibility and Judgment.]

Aristoteles. Die Nikomachische Ethik. Greek-German. Translation Olof Gigon. Ed. Rainer Nickel. Düsseldorf/Zürich 2007: Artemis \& Winkler. [The Nicomachean Ethics]

Bourdieu, Pierre. (1976). Ehre und Ehrgefühl. In ders.: Entwurf einer Theorie der Praxis auf der ethnologischen Grundlage der kabylischen Gesellschaft, 11-46. Frankfurt am Main: Suhrkamp. [“The sense of honour.” Pp. 95-133 in Algeria 1960, translated by R. Nice. Cambridge: Cambridge University Press.]

Bourdieu, Pierre. (2000) [French Original: 1977]. Die zwei Gesichter der Arbeit. Interdependenzen von Zeit- und Wirtschaftsstrukturen am Beispiel einer Ethnologie der algerischen Übergangsgesellschaft. Konstanz: UVB. [No English version found]

Çağatay, Neşet. (1990). Ahiliknedir? Türkiye Esnaf ve Sanatkârları Konfederasyonu Yayın No: 40. Ankara. [What is “Ahilik”?].

Damasio, Antonio. (2005). Descartes’ error. Emotion, reason and the human brain. London: Penguin Books.

Dinçer, Gökçe. (2014). Sahte halıya dört yıl sonar dava. 18.04.2014, Hürriyet gazetesi. www.hurriyet.com.tr/ekonomi/26238890.asp. Accessed 20 May 2018. [Fake Carpet. Trial after four years]. 
Durkheim, Émile. (1991). Physik der Sitten und des Rechts. Vorlesungen zur Soziologie der Moral. Frankfurt am Main: Suhrkamp. [No English version found]

Durkheim, Émile. (1992) [French Original 1893]. Über soziale Arbeitsteilung. Studie über die Organisation höherer Gesellschaften. Frankfurt am Main: Suhrkamp. [Division of Labour in Society]

Gerste, Margrit. (1997). Endlich: Vergewaltigung in der Ehe gilt künftig als Verbrechen. 16 May 1997, www.zeit.de/1997/21/ehe.txt.19970516.xml. Accessed 28 April 2018. [Finally: Marital rape will be considered a crime in the future]

Goleman, Daniel. (1996). The Emotional Intelligence. Why it can matter more than IQ, London.

Habermas, Jürgen. (1981). Theorie des kommunikativen Handelns, 2 Bde; Frankfurt am Main: Suhrkamp. [The Theory of Communivative Action]

Hausman, Daniel and Michael McPherson. (1993). Taking ethics seriously: economics and contemporary moral philosophy. In Journal of Economic Literature, 31, 671-731.

Hüwelmeier, Gertrud. (2004). Zur Ethnographie des Mittelmeerraumes: lokal, regional, transrational. In Schweizerisches Archiv für Volkskunde 100, 65-78. [On the ethnography of the Mediterranean: local, regional, transrational]

Kersting, Wolfgang. (2002). Kontraktualismus. In M. Düwell u.a. Handbuch Ethik. 163-178. Stuttgart: J.B. Metzler. [Contractualism. In Handbook Ethics]

Köknel, Suat and İlber Ortaylı. (2007). From Guild to Chamber. For the 125th Anniversary of the Istanbul Chamber of Commerce, Istanbul. www.ito.org.tr/itoyayin/0018310.pdf. Accessed 15 May 2018.

Korff, Wilhelm. (1966). Ehre, Prestige, Gewissen. Köln: J.P. Bachem Verlag. [Honour, Prestige, Conscience]

Küçükerman, Önder and Kenan Mortan. (2009). Der Große Basar und die Geschichte des Handels in Anatolien. Hückelhoven: Verlag Anadolu [Turkish Original 2007: Kapalıçarş1]. [Istanbul and The Grand Bazaar]

Küng, Hans. (1991). Projekt Weltethos. München, Zürich: Piper. [The World Ethos Project]

Mauss, Marcel. (1966). The Gift. The form and reason for exchange in archaic societies. London: Cohen \& West.

Müller, Hans-Peter and Michael Schmid. (1992). Arbeitsteilung, Solidarität und Moral. Eine werkgeschichtliche und systematische Einführung in die, Arbeitsteilung' von Émile Durkheim. In Durkheim, Émile: Über soziale Arbeitsteilung. Studie über die Organisation höherer Gesellschaften, 481-522. Frankfurt am Main: Suhrkamp.

Özbey, Atilla. (2010). İstanbul-The Grand Bazaar: From Past to Present. İstanbul Ticaret Odas1. www.ito.org.tr/itoyayin/0022166.pdf. Accessed 28 May 2018.

Pamuk, Şevket. (2001). Osmanlı'daloncalar./ Ottoman guilds: the loncas. In Kapalı Çarşı Dergisi, Ekim 2001/2-3/. The Grand Bazaar Magazine, October 2001/ 2-3. Istanbul, 45-49; 64-70.

Peristiany, J. G. (1965). Honour and Shame. The value of Mediterranean Societies. London.

Petersen, Andrea. (1985). Ehre und Scham. Das Verhältnis der Geschlechter in der Türkei. Berlin. Honour and Shame. The Relationship between the Sexes in Turkey]

Platon. Der Staat. Über das Gerechte. Translatedby Otto Apelt. Köln 2010: Anaconda Pitt-Rivers, Julian. 1971 [1954]. The people of the Sierra. Chicago \& London.

Rawls, John. (1971). A Theory of Justice. Cambridge. Rawls, John. 1993. Political Liberalism. Columbia University.

Riesman, David. (1950). The Lonely Crowd. A study of the changing American Character. Yale University Press.

Röhl, Klaus. (1987, 2013). Kapitel 5: Verhaltens- und handlungstheoretische Erklärungsansätze. In ders.: Rechtssoziologie, 145-216. www.ruhr-uni-bochum.de/rsozinfo/. Accessed 27 March 2018. [Behavioral and action-theoretical explanatory approaches. In ders: Sociologyof Law]

Şatıroğlu, Ayşen and Oya Okan. (2010). Çarşı - Esnaf. Kapalıçarşı. İstanbul Ticaret Odası. İstanbul [Basar - Handwerk. Der Große Basar] www.ito.org.tr/itoyayin/0024483.pdf. Accessed 15 May 2018. [Bazaar - Craftsmenship. The Grand Bazaar]

Schiffauer, Werner. (1983). Die Gewalt der Ehre. Erklärungen zu einem deutsch-türkischen Sexualkonflikt. Frankfurt am Main: Suhrkamp. [The Violence of Honor. Explanations of a German-Turkish Sexual Conflict.]

Sennett, Richard. (2009). The Craftsman. London: Penguin Books.

Sigg, Gabriele and Andreas Zimmermann. (2018). Emotionale Bildung. Die vergessene Seite der Bildungsdebatte. Hamburg: Verlag Dr. Kovac. [Emotional Education. The forgotten side of the education debate]

Sigg, Gabriele Maria. (2017). Ehre revisited. Die Charakterhaltung als gesellschaftliche Grundlage. Dissertation. Baden-Baden: Tectum Verlag. [Honourrevisited. The character attitude as a social foundation]

Simmel, Georg. (1992). Soziologie. Untersuchungen über die Formen der Vergesellschaftung. Frankfurt am Main: Suhrkamp. [Sociology. Inquiries into the Construction of Social Forms] 
Sombart, Werner. (1913). Der Bourgeois. Zur Geistesgeschichte des modernen Wirtschaftsmenschen, München, Leipzig: Verlag von Dunder und Humblot. [The quintessence of capitalism]

Stewig, Reinhard. (2009). From Bazaar to Shopping Center in Istanbul. Hamburg-Schenefeld: EB-Verlag.

Veblen, Thorstein. (1899). The Theory of the Leisure Class. An Economic Study in the Evolution of Institution. London: Macmillan.

Weber, Max. (2005). Der Geist des Kapitalismus und die Protestantische Ethik. Erfstadt: Area Verlag. 